\title{
The Darfur Situation and The ICC: An Appraisal
}

\author{
Omer Y. Elagab \\ City Law School, City University London \\ Northampton Square, London EC1V 0HB, UK \\ Tel: 44-20-7040-8310Ｅ-mail: o.y.elagab@city.ac.uk
}

\begin{abstract}
On 31 March 2005, the Security Council adopted Resolution 1593 referring the situation in Darfur, Sudan, to the Prosecutor of the International Criminal Court (ICC). In accordance with the Rome Statute, the Prosecutor commenced his investigation and presented evidence to Pre Trial Chamber I (PTC I), implicating two Sudanese men in the commission of crimes against humanity and war crimes in Darfur. Consequently, the Chamber has issued Warrants for their arrest. This chain of events has given rise to a number of jurisprudential issues which will be discussed here, namely, the legal significance of the referral by the Security Council to the ICC; the various grounds of jurisdiction of the ICC and personal responsibility for atrocities committed; the questions of admissibility complementarity, and double jeopardy.
\end{abstract}

Keywords: Darfur, ICC, Security Council, Crimes Against Humanity, Genocide, War Crimes, Complimentarity

\section{The Purpose}

This paper attempts to discuss some of the issues raised by the UN Security Council referral of the situation in Darfur to the ICC. The paper begins by offering analysis of the jurisdiction of the ICC in the context of subject-matter of international crimes (genocide, crimes against humanity, war crimes and aggression). This will be followed by an evaluation of international criminal responsibility of the two accused Sudanese nationals. The conclusions reached by the ICC in this respect will also be alluded to. Some questions of principle will be discussed. Admissibility will be referred to, as will the important regimes of complementarity and double jeopardy. Thereafter the relationship between the Security Council and the ICC will be assessed.

\section{Background}

The conflict in the Darfur Region of Sudan began in February of 2003. At least 400,000 people have been reportedly killed; more than 2.5 million civilians are displaced. They now live in displaced-persons camp in Sudan or in refugee camps in neighbouring Chad; and more than 3.5 million men, women, and children are completely reliant on international aid for survival.

When shown a picture of a US State Department map depicting burnt villages in Darfur during an NBC News interviews in Khartoum, President Bashir of Sudan called it a 'fabrication'. Adding that, 'Yes, there have been villages burnt but not to the extent you are talking about. People have been killed because there is war. It is not the Sudanese culture or people of Darfur to rape. It does not exist. We do not have it' (See Note 1). Bashir linked the photograph to pictures shown by former US Secretary of State Colin Powell at the UN Security Council before the start of the Iraq war as proof of the presence of weapons of mass destruction in Iraq. No such weapons have been found since the war started 5 years ago.

The Sudanese armed forces and Sudanese government-backed militia known as "Janjaweed" have been fighting two rebel groups in Darfur, the Sudanese Liberation Army/Movement (SLA/SLM) and the Justice and Equality Movement (JEM) (See Note 2). The stated political aim of the rebels has been to compel the government of Sudan to address under-development and the political marginalization of the region. In response, the Sudanese government's regular armed forces and the Janjaweed - largely composed of fighters of Arabic nomadic background- have targeted civilian populations and ethnic groups from which the rebels primarily drew their support - the Fur, Masalit and Zaghawa (See Note 3).

On March 2005, the Security Council adopted Resolution 1593 referring the situation in Darfur to the Prosecutor. In accordance with the Rome Statute, the Prosecutor opened an investigation in relation to that on 1 June 2005. After a lengthy investigation into crimes allegedly committed in Darfur since 1 July 2002, the Prosecutor had on 27 February 2007 applied to PTC I to issue summonses to appear against Ahmad Harun and Ali Muhammad Ali Abd-Al-Rahman 
(also known as Ali Kushayb). Not confident that the two men would voluntarily surrender themselves, the Chamber issued Warrants of Arrest against them. The interaction between the government of Sudan and the ICC evolved into outright hostility after the ICC judges issued Arrest Warrants in April 2007 for the two men. Sudan has categorically rejected the jurisdiction of the ICC over the cases and called the Prosecutor "junior employee doing cheap work" (See Note 4). It is most unlikely that these warrants would be enforced, as the government of Sudan is adamant not to surrender the two men.

\section{Jurisdiction}

The ICC differs a great deal from all previous international tribunals as far as territorial and personal jurisdiction are concerned. The Nuremberg Tribunal exercised personal jurisdiction over persons who had committed one of the crimes within the Tribunal's subject-matter jurisdiction (See Note 5). The jurisdiction of the International Criminal tribunal for former Yugoslavia (ICTY) is territorial in nature as it is confined to crimes committed on the territory of that country, after 1991 (See Note 6). By contrast, the jurisdiction of the International Criminal Tribunal for Rwanda (ICTR) is both territorial and personal as it spans over crimes committed in 1994 and over crimes committed by nationals of that country in neighbouring states during the same era (See Note 7).

As against these precedents, the ICC is created by the Assembly of States who have voluntarily agreed to be themselves subjected to its jurisdiction. Moreover, the jurisdiction of the ICC is somewhat less expansive than the jurisdiction exercised by individual States over the same crimes. A further limitation imposed by the Rome Statute on the jurisdiction of the ICC is that, national courts are given priority to exercise jurisdiction over offences and only when they become "unwilling" or "unable" to prosecute can the ICC intervene. This is refereed to in the Statute as admissibility. At this juncture it should be noted that although the Rome Statute recognises the interrelation between these two concepts (jurisdiction and admissibility) yet it draws clear distinction between them.

As concerns jurisdiction, it relates to the scope of the ICC operation in terms of (a) subject-matter (jurisdiction ratione materiae); (b) temporal (jurisdiction ratione temporis); (c) space (jurisdiction ratione loci); and (d) jurisdiction over individuals (ratione personae). The issue of admissibility comes up at a later stage, and its purpose is to establish whether alleged offences over which the Court has jurisdiction should be litigated before it. A further distinction between the two concepts is that rules of jurisdiction are rather rigid as compared with admissibility which admits a degree of flexibility. Having said that, it has to be admitted that the demarcation line between the two categories is not always easy to identify. This may be illustrated by Article 17 (1) (d) of the Statute which deals with admissibility. That provision inhibits the jurisdiction of the ICC to proceed with a case which is not of sufficient gravity. Conversely, Article 8 (1) of the Statute empowers the ICC to exercise jurisdiction with respect to war crimes, in particular when committed as part of a plan or policy or as part of a large scale commission of such crimes.

\subsection{Subject matter jurisdiction (ratione materiae)}

The ICC has jurisdiction over four categories of international crimes, namely genocide, crimes against humanity, war crimes and crimes of aggression (Article 5(1) (a) to (d)). The gravity of these crimes is described in both the preamble to the Rome Statute and its Article 9 as "the most serious crimes of concern to the international community as a whole." (See Note 8)

\subsubsection{Genocide}

Article 6 of the Rome Statute adopts the same definition of genocide as the 1948 Genocide Convention (See Note 9). In view of this, reference may first be made to the Genocide Convention and how it has been interpreted by competent international tribunals. The text of Article 2 of the that Convention defines genocide as meaning any of the following acts committed with intent to destroy, in whole or in part, a national, ethnical, racial or religious group, as such:

(a) Killing members of the group;

(b) Causing serious bodily or mental harm to members of the group;

(c) Deliberately inflicting on the group conditions of life calculated to bring about its physical destruction in whole or in part;

(d) Imposing measures intended to prevent births within the group;

(e) Forcibly transferring children of the group to another group.

This provision can be without a doubt regarded as a part of customary law corpus and as such has been also accepted by two ad hoc international criminal tribunals. Both statutes of the ICTY and the ICTR share the same definition of genocide as the 1948 Genocide Convention.

The systematic rape, humiliation and mutilation that occurred in Rwanda in 1994 resulted in very serious physical and psychological traumatic experience, not only to the Tutsi women, but also to members of their families and community at large. The ICTR handed down for the first time ever a conviction for genocide in the Akayesu case (See Note 10). 
The ICTR ruled in that case that, acts of sexual violence may "constitute genocide in the same way as any other act as long as they were committed with the specific intent to destroy, in whole or in part, a particular group, targeted as such." (See Note 11)

Moreover, in the Kayishema and Rutaganda Cases, (See Note 12) the ICTR found that sexual violence satisfies the definitional requirements of "causing serious bodily or mental harm to members of the group, deliberately inflicting on the group conditions of life calculated to bring about its physical destruction in whole or in part and imposing measures intended to prevent births within the group."(See Note 13)

In a similar vein, the ICTY stated in the Jelisic Case, (See Note 14) that "genocide is characterized by two legal ingredients according to the terms of Article 4 of the Statute: (1) the material element of the offence, constituted by one or several acts enumerated in paragraph 2 of Article 4; and (2) the mens rea of the offence, consisting of the special intent to destroy, in whole or in part, a national, ethnical, racial or religious group, as such."(See Note 15)

Consequently, it results from the accepted legal definition that the murder of a large number of victims does not necessarily equate to genocide. On the other hand, the murder of a single person could constitute an attempt at genocide "if the aggressor's intent was to kill that person as part of larger plan to destroy a group."(See Note 16) In fact, genocide could occur in the absence of killings.

In the light of the definition presented above, it is abundantly clear that the Government of Sudan has not committed the crime of genocide in the region of Darfur as the legal elements of that offence cannot be established. In short, although there are serious allegations of mass murder and massacres against the Government of Sudan, no credible charges of genocide could be brought against its officials.

For its part, the US Government seems to take an opposing view. Thus, in a testimony before the Senate Foreign Relations Committee on 9 September 2004, the then US Secretary of State, Colin Powell, declared that the fighting in Darfur was "genocide". Although, this was an extremely alarming allegation, none of the remaining Permanent Members of the Security Council supported it. Moreover, a report submitted by an International Commission of Inquiry on Darfur, set up under UN Security Council Resolution 1564 (2004) expressly absolved the Sudanese Government of pursuing "a policy of genocide"(See Note 17). Having said that, the Commission warned that,

"The conclusion that no genocide policy has been pursued and implemented in Darfur by the Government authorities, directly or through the militias under their control, should be taken in any way as detracting from the gravity of the crimes perpetrated in that region. International offences such as the crimes against humanity and war crimes that have been committed in Darfur may be no less serious and heinous than genocide" (See Note 18).

Although, the occurrence of genocide in Darfur is contentious, it should always be remembered that these claims are exclusively based on reports of NGO's and the media. Moreover, consistent with the above findings, the ICC Prosecutor stated in his Fourth Report to the Security Council that he collected sufficient evidence to back up charges of crimes against humanity and war crimes, but not genocide (See Note 19).

\subsubsection{Crimes Against Humanity}

As has been mentioned hitherto, crimes against humanity are within the jurisdiction of the ICC. The elements of this type of crime will be analysed with a view to ascertaining what the Prosecutor will have to prove in order to establish that the alleged conduct amounts to crimes against humanity.

The Rome Statute defines crimes against humanity in Article 7(1) as unlawful acts "committed as part of a widespread or systematic attack directed against any civilian population, with knowledge of the attack". The same Article goes on to list murder, extermination, enslavement, deportation, arbitrary detention, torture, rape, persecution on political, racial and religious grounds, and other inhuman acts that can qualify as crimes against humanity. It should be emphasised that the attack against a civilian population should either be on a widespread basis or in a systematic manner, but not necessarily both (See Note 20). Furthermore, culpability of crimes against humanity requires that the perpetrator has the relevant knowledge of the attack against the civilian population. Article 7 of the Rome Statute appears to accept the rule stated by the ICTY Trial Chamber in Blaskic case (See Note 21) that, while there is no necessity for identifying the perpetrator with a policy or plan underlying crimes against humanity, it is sufficient that he or she has knowledge of the attack.

As concerns the Darfur situation, the Commission of Inquiry reported that the term "Janjaweed" was employed to describe members of Popular Defence Force, other government agencies as well as Arab militia. In any event, the Commission saw no merit in distinguishing between the three groups, as they were all guilty of " violation of international human rights law and humanitarian law"(See Note 22) and that there were direct links between these three groups and the Government of Sudan.

As hereto mentioned, on 27 February 2007, pursuant to Article 58(7) of the Statute, the Prosecutor applied to PTC I, requesting it to issue summonses to appear against the two suspected Sudanese men. The allegation centred around the 
following points (See Note 23):

- The crimes were perpetrated in the context of a non-international armed conflict in the Darfur region between the Government of the Sudan and rebel forces.

- The Sudanese Armed Forces and Militia/Janjaweed attacked the villages based on the rationale that the tens of thousands of civilian residents living in the villages supported the rebel forces.

- Mass murder, summary execution, mass rape, forced displacement of entire communities and other grave crimes were committed against civilians who were non-combatants.

Turning to the determination made by the PTC I, in accordance with Article 19(1) of the Statute, the PTC I had to satisfy itself that it had jurisdiction in the case brought before it by the Prosecutor. On the basis of the evidence and information supplied to it, the judges of the PTC I ruled that "without prejudice to any challenge to the admissibility of the case under article 19(2) (a) and (b) of the Statute and without prejudice to any subsequent determination",(See Note 24) they found that the case against Ahmad Harun and Ali Kushayub fell within the jurisdiction of the ICC and appeared to be admissible.

As concerns the question of whether there were reasonable grounds to believe that the contextual elements of at least one crime against humanity within the jurisdiction of the Court had been met, the PTC I stated thus:

"Having considered and analysed the Prosecution Application and its supporting material,..., the Chamber is of the view that the information contained in the documents leads it to conclude that there are reasonable grounds to believe that during the period relevant to the Prosecution Application, the specific elements of crimes against humanity within the jurisdiction of the Court were met under article 7(1) (a), 7(1) (d), 7(1) (e), 7(1) (f), 7(1) (g), 7(1) (h) and 7(1) (k) of the Statute." (See Note 25)

These findings leave the two accused or the Government of Sudan with the option of challenging the jurisdiction of the ICC or the admissibility of the case under Article 19(2) (a) and 19(2) (b) respectively. However, as the PTC I noted, the Sudanese Ministry of Foreign Affairs had stated in a public document that, Sudan would not cooperate with the ICC as it had no right to extend its power over Sudanese territory or Sudanese citizens (See Note 26).

\subsubsection{War Crimes}

Article 8 of the Statute of Rome deals in extensive details with war crimes. In fact it is the longest provision in the Statute, and indeed also the lengthiest when compared with its antecedents (the Nuremberg Charter and the four Geneva Conventions). This Article can be seen as a progressive development of the rules applicable to war crimes, seeing that it expressly brings non-international conflicts under its ambit. Not only that, but it also defines war crimes in considerable details. Moreover, the Article divides these crimes into four categories, two for international armed conflicts, and two for non-international armed conflict.

In the context of the conflict in Darfur, it is proposed to deal with the part of the provisions applicable to armed conflict not of an international character. Thus, Article 8(c) embraces all serious violations of Article 3 common to all four Geneva Conventions. However, these crimes are only prosecutable before the ICC if they were committed against 'protected persons'. This term includes persons (civilians) who are taking no active part in the hostilities and members of the armed forces who became hors de combat for whatever reason. The crimes listed consist of murder, mutilation, cruel treatment and torture, outrages upon personal dignity, taking of hostages and summary executions.

The other category of offences relating to armed conflict not of an international character is contained in paragraph (e) of Article 8. They include attacks that are intentionally directed against civilians, cultural buildings, hospitals, humanitarian workers (including those from Red Cross and Red Crescent organisation) and peacekeeping missions. The Article also punishes all forms of sexual abuse, such as rape, sexual slavery, enforced prostitution, forced pregnancy and any other form of sexual violence.

Article 8 does not provide jurisdictional threshold for war crimes, unlike the case with crimes against humanity where widespread or systematic abuse must be established as prevalent. It is also unlike genocide where very high level of specific intent must be established. In a curious way, Article 8(1) endeavours to remedy that situation by introducing what came to be known as "non-threshold threshold" (See Note 27). This stipulates that the ICC has jurisdiction in respect of war crimes in particular when committed as part of a plan or policy as part of a large scale commission of such crimes.

However, the treatise known in the Rome Statute as the Elements of Crimes makes the task of the Prosecutor less onerous, as he is not obliged to establish the aforesaid threshold element of war crimes. According to this, he is not required to prove that the alleged perpetrator knew of the existence of the armed conflict or its designation.

In considering whether there were reasonable grounds to believe that the contextual element of at least one war crime within the jurisdiction of the Court was present, the PTC I determined as follows: 
"Having considered and analysed the Prosecution Application and its supporting material, in particular the report of the International Commission of Inquiry on Darfur and witness statements, the Chamber is of the view that the information contained in the documents leads it to conclude that there are reasonable grounds to believe that, between August 2003 and March 2004, the specific elements of war crimes within the jurisdiction of the Court were met under article 8(2)(c)(i), 8(2)(c)(ii), 8(2)(e)(i), 8(2)(e)(v), 8(2)(e)(vi), 8(2)(e)(xii) of the Statute." (See Note 28)

A word of caution has to be said at this juncture, namely, that the nature and the weight of the evidence may be questionable. This is because although the Prosecutor took considerable period to investigate the situation in Darfur, in the end he relied exclusively on secondary data such as testimonies taken from witnesses scattered in 17 countries and also the report of the International Commission. One would have thought that the office of the Prosecutor with its good resources should have come up with primary evidence. Furthermore, although these are early stages of the prosecution, concern is raised as to the ease with which the Court has readily accepted the supporting material submitted to it along with the Prosecution Application.

\subsection{Temporal Jurisdiction (Jurisdiction Ratione Temporis)}

According to Article 11 of the Rome Statute, the ICC has no jurisdiction retrospectively: it can only prosecute crimes committed on or after 1 July 2002, the date on which the Rome State entered into force. Where a State becomes party to the Rome Statute after that date, the Court can exercise jurisdiction automatically with respect to crimes committed after the Statute enters into force for that State. The Rome Statute seems to repeat the principle of non-retroactivity contained in Article 11 into Article 24 as follows:

No person shall be criminally responsible under this Statute for conduct prior to the entry into force of the Statute.

In fact the two Articles (11 and 24) could easily have been merged at the time of drafting them (See Note 29).

Its has to be admitted, however, that there is a notable exception to the principle of non-retroactivity of the Rome Statute in the form of making an ad hoc declaration recognising the jurisdiction of the Court over specific crime, even if the State is not a party to the Statute. This provision is stipulated for in Article 12 (3), obviously does not encompass crimes committed prior to 1 July 2002, nor for that matter referrals by the Security Council for crimes preceding that date.

This limitation on the jurisdiction of the Court is logical, otherwise the Court would have been able to dig into events of the distant past. At the same time, one can see the drawback of this argument, namely, the provision of immunity from prosecution for those who committed atrocities prior to the date on which the Rome Statue came into force.

Applying this legal narrative to the situation prevailing in Darfur, it would be recalled that the referral by the Security Council to the Prosecutor was expressly stated in relation to events only since 1 July 2002 (See Note 30). Clearly, therefore, both the Security Council and the office of the Prosecutor have acted within the terms of the Rome Statute, as far as events predating its coming into force.

\subsection{Territorial jurisdiction (Ratione loci jurisdiction)}

The general principle regarding the jurisdiction of the ICC over crimes committed on the territory of the State parties, regardless of the nationality of the offender is set out in Article 12 (2) (a) of the Statute. As concerns referral of cases by the Security Council under Chapter VII, Article 13 (b) of the Statute entitles the ICC to exercise jurisdiction over all the crimes listed in Article 5, if such crimes appear to have been committed within the territory of the State in question.

As concerns the Darfur situation, clearly the ICC has no jurisdiction under Article 12 (2) (a) because the Sudan is neither a party to the Statute, nor has it accepted the jurisdiction of the Court with respect to any given crime. If either limb of jurisdiction was applicable then the Sudan would have been obliged under Article 12 (3) of the Statute to co-operate with the Court without delay or exception.

Having said that, it is arguable that the ICC could have territorial jurisdiction over the situation in Darfur, this may be possible under Article 13(b) of the Statute as the crimes identified by the prosecutor were allegedly committed within Sudanese territory. The judges of the ICC seem to have accepted that there were reasonable grounds to believe that the two Sudanese men in question had committed war crimes in the region of Darfut in Sudan.

Notwithstanding that, Sudanese authorities have refused to hand over the suspects. The Minister of Justice is on record to have stated:

"We do not recognise the International Criminal Court ... and we will not hand over any Sudanese even from the rebel groups who take up weapons against the government." (See Note 31)

To conclude this point, the issue of territorial jurisdiction is not contentious with regard to the situation in Darfur. This is because none of the fighting factions dispute the fact that the human suffering and alleged crimes took place within the boundaries of Sudan. The fact that civilians fled to Chad does not compromise the territoriality of the crimes committed. 


\section{Individual Criminal Responsibility}

Article 25 of the Rome Statute addresses the issue of individual responsibility as two categories. The first comes under paragraph 3(b) and covers primary offenders who order, solicit or induce the crimes in question. The second category comes in paragraph 3(c) and covers secondary parties (known as accomplices) who aid, abet or otherwise assist primary offenders in committing the crimes in question.

Article 25(3) (d) deals with complicity in a criminal enterprise where a person contributes to the commission or attempted commission of such a crime by a group or persons acting with a common purpose. The same Article deals further with notion of attempt in paragraph (3) (f). It requires that, before responsibility can be attached, the individual concerned must have taken substantial steps towards the commission of the offence, but due to circumstances beyond his control the offence is not committed. On the other hand, criminal responsibility will not attach where the individual in question voluntarily and intentionally abandons his efforts to commit the crime, or prevents its consummation by others.

Leaving substantive aspects of the crimes aside, Article 27 stipulates that criminal responsibility under the Rome Statute applies to all persons irrespective of official capacity, including inter alia members of Governments and government officials. Moreover, Article 29 stipulates that the crimes within the jurisdiction of the Court shall not be subject to any statute of limitations. All other germane matters are to be dealt with under Article 28. According to its provisions, the Commanders or other superiors may be culpable for failing to prevent crimes committed by their subordinates. The responsibility is not confined to military Commanders, as it also attaches to civilians who are effectively acting as military Commanders.

The view held by Human Rights Watch is that:

"In Darfur, individuals such as militia leaders, soldiers, and pilots involved in bombing campaigns, military commanders, and government officials who directly participated in, planned, ordered, or were otherwise complicit in the commission of war crimes and crimes against humanity can be found criminally liable for these activities in international courts, regardless of the presence of Sudanese amnesty or immunity laws. Some of these individuals including those named in this report — both civilian and military — may also be liable for war crimes or crimes against humanity under the theory of command responsibility."(See Note 32)

The Prosecutor offered a summary of a one hundred pages document containing his evidence on which he based his allegations of complicity on the part of the two named Sudanese persons.

The Application of the Prosecutor raised the following matters:

After the attack on Al Fashir, Ahmad Harun was appointed as Sudanese Minister of State for the Interior by the regime in April 2003, to head the "Darfur Security desk".

He further asserted that Ahmad Harun recruited Militia/Janjaweed with full knowledge that they, often in the course of joint attacks with forces of the Sudanese Army, would commit crimes against humanity and war crimes against the civilian population of Darfur.

Moreover, the Prosecutor alleged that statements and speeches made by Harun while in Darfur demonstrate that he had full knowledge that the Militia/Janjaweed were routinely attacking civilian populations and committing crimes against them.

As concerns Ali Kushayb, the Prosecutor accused him of commanding thousands of Militia/Janjaweed by mid-2003, and that he personally led Militia/Janjaweed at the attacks upon Kodoom, Bindisi, Mukjar, and Arawala.

A further allegation made against Ali Kushayb was that, in December 2003, he personally inspected a group of naked women in Arawala before they were raped by men under his command. The victims were tied to trees with their legs apart and continually raped.

The significant allegation by the Prosecutor was that Ahmad Harun and Ali Kushayb joined each other, and others, in pursuing the shared and illegal objective of persecuting and attacking civilian populations in Darfur.

In conclusion, the Application alleges that Ahmad Harun and Ali Kushayb bore criminal responsibility in relation to 51 counts of war crimes and crimes against humanity including: rape; murder; persecution; torture; forcible transfer; destruction of property; pillaging; inhumane acts; outrage upon personal dignity; attacks against the civilian population; and unlawful imprisonment or severe deprivation of liberty.

Acting under article 58(7) of the Rome Statue, PTC I decided on 27 April 2007 to issue Warrants of Arrest for Ahmad Harun and Ali Kushayb for their alleged responsibility for crimes against humanity and war crimes. The decision set out that the case against Harun and Kushayb fell within the jurisdiction of the Court and was admissible. It further stated that there were reasonable grounds to believe that the crimes described in the Application have been committed and that there were also reasonable grounds to believe that Harun and Kushayb were criminally responsible for the crimes. 
Based on the information provided by the Prosecution, PTC I was not satisfied that summons to appear were sufficient to ensure Harun's and Kushayb's appearance before the Court and therefore issued arrest warrants instead. PTC I also decided that the Registry shall prepare two requests for cooperation seeking the arrests and surrender of Harun and Kushayb (See Note 33).

Sudanese authorities have made it abundantly clear that they had no wish to comply with the provisions of Article 59 of the Statute. This non-compliance may be inconsistent with the terms of the UN Security Council Resolution 1593. It will be recalled that, the Security Council referred the situation in Darfur to the ICC under that resolution. Moreover, it required under that Resolution the cooperation of the Government of Sudan with the Court even though it is not a State party to the Rome Statute. As the legality of that Resolution is a contentious matter, it is arguable that Sudanese authorities could insist that it becomes the subject matter of an Advisory Opinion before the International Court of Justice (ICJ). If this line of argument is persuasive, the Security Council could then suspend proceedings before the ICC until the legality of the Resolution is established.

\subsection{Some questions of principle on individual criminal responsibility and crimes against humanity}

As we stated, the ICC issued its first Warrants of Arrest for suspects accused of war crimes and crimes against humanity in Sudan's Darfur region in early May 2007. As already indicated the warrants were issued for the arrest of Ahmed Harun, a cabinet minister, and Ali Kushayb who is a militia commander. The INTERPOL has circulated a notice for the arrest of both men soon thereafter.

The Prosecutor has announced on 13 March 2008, that he is currently finalising two more investigations into the atrocities in Darfur to be presented by the Court by the end of this year. The Prosecutor has indicated that one of the investigations relates to involvement of Sudanese officials in attacks against civilians while the other looks at rebel attacks against peacekeepers and aid workers. It is significant that the Prosecutor stated that, "[his] office will proceed to investigate who is bearing the great responsibility for ongoing attacks against civilians; who is maintaining Harun in a position to commit crimes; who is instructing him" (See Note 34). The Prosecutor seems here to invoke Article 28 of the Rome Statute which imposes command responsibility. This concept applies not only to military personnel, but also to civilian superiors. Successful invocation of that provision will depend on the prosecution's ability to establish the three elements required for that, namely, (a) existence of superior-subordinate relationship; (b) the superior must have known or had reason to know that the subordinate was about to commit a crime or had committed a crime; and (c) the superior must have failed to take necessary and reasonable measures to prevent the crime or punish the perpetrator.

Leaving aside these disclosures by the Prosecutor, it has now been one year since the Arrest Warrants have been issued and the Sudanese government made no attempt to hand over the two suspects. What is more, the UN Security Council which asked the ICC to investigate Darfur crimes under a Chapter VII mandate in resolution 1593 some three years ago, appears to be reluctant to subdue Sudan into surrendering the said two suspects. Even more than that in September 2007 three members of the Security Council (China, Russia and Qatar) blocked the Presidential Statement supporting the arrest and extradition of the two individuals in question.

This state of affairs raises several questions of principle. First, was it prudent of the Prosecutor to proceed with two names only on his original application to the PTC I? This limitations was done with total oblivion to the cry by the preponderant majority of credible human rights organisations to go for more names. Secondly, the question is begged as to the extent to which the ICC Prosecutor relied on the Report of the International Commission on Darfur as a basis for his application of February 2007. This point should be understood in the context of the sealed envelope handed over from the Security Council to the Prosecutor when the situation in Darfur was referred to him in March 2005. It is now common knowledge that that envelope contained a list of fifty-one individuals named as suspects of committing serious crimes under international law. The Prosecutor sealed off the envelope again as quickly as he opened it, saying that the list was a mere advice to him and that it carried no mandatory status whatsoever. The Prosecutor was at pains to point out that, his Office and the International Commission on Darfur have two entirely different mandates. He then went on to state specifically that the list of names identified by that Commission would not bind his selection of suspects. Thirdly, it would seem that the Prosecutor has unfettered discretion whether to prosecute or not. This is in accordance with Article 53 of the Rome Statute which impels the Prosecutor to prosecute only upon being in possessions of sufficient evidence which gives rise to reasonable grounds for believing that the suspect in question must have committed crimes within the jurisdiction of the Court. Thus, the Prosecutor is obliged to carefully review the evidence in terms of scale, nature, manner of commission and impact of crime. Whatever the may be the case now, time will tell whether the attitude adopted by the Prosecutor in relation to Darfur lays a solid foundation for the future of international criminal litigation or not.

Trial in absentia is another matter that is raised by the refusal to hand over the two accused to the ICC (See Note 35). The simple and straightforward answer is that, the Rome Statute does not allow for trial in absentia. It does, however, allow for confirmation of charges in the absence of the accused, but this does not seem to be an option currently pursued. Even, where that is the case, it is doubtful whether that would fulfil any of the aims of international criminal litigation. 
The same can also be said about staging a fully fledged trial in absentia with all the huge financial costs involved.

\section{Admissibility Under the Rome Statute}

The starting point is that, admissibility and jurisdiction are two related concepts. As stated before, Jurisdiction refers to competence of the ICC under the Statute, and it embraces subject matters, time and individuals. On the other hand, the applicability of the domestic jurisdiction over perpetrators of crimes, or the submission of such persons to the jurisdiction of the ICC is what the Statute refers to as admissibility. A case will be deemed admissible before the ICC, if the criteria listed in Article 17 of the Statute are fulfilled. The most important of these criteria, in the context of Darfur is the one which enforces the inadmissibility of a case before the ICC, on the ground that it has been properly investigated, with prosecution being carried out by or otherwise opposed by the organ of the State which possesses competent jurisdiction over that case (See Note 36).

To avoid abuse of the system, the aforesaid criteria are made subject to a number of exceptions to safeguard against impunity, as the general idea of the Statute is to put an end to impunity. The rules in the Statute are precisely designed to remove any possibility of powerful individuals escaping justice. It is precisely for this reason that the ICC is empowered to prosecute a case when a State with competent jurisdiction is unwilling or unable to utilise its domestic system to carry out investigation or prosecution of an individual who allegedly committed international crimes, or when the decision not to take an action against such individual is the result of the unwillingness or inability of the competent State to genuinely prosecute.

As mentioned previously, on 31 March 2005, the UN Security Council took an unprecedented step by referring the situation in Darfur to the ICC. That referral was within framework of Security Council Resolution 1593 (2005) and was in marked contrast to the three earlier referrals of the situation in Uganda (2003), the Democratic Republic of Congo (2004) and Central African Republic (2005). The three States mentioned here have pledged their unqualified support to the ICC, while the Sudanese government is opposing the admissibility of the case before the ICC from the outset most and foremost on grounds of jurisdiction and complementarity. This will be the next item to be discussed.

\section{The Complementarity Regime}

According to paragraph 10 of the Preamble and Article 1 of the Rome Statute, the ICC 'shall be complementary to national criminal jurisdictions'.

This must, however, be read in conjunction with the primary objective of the legal regime created by the Rome Statute. This provides that, criminal jurisdiction over persons who commit the most serious crimes of international concern should in principle be exercised by the national courts, rather than by the ICC. To make this possible, the Statute has come up with the principle of complementarity, encompassing a number of procedures for testing admissibility of the cases before the ICC which must be satisfied before any such case can be heard before the ICC. When these procedures are not fulfilled, then the jurisdiction of the ICC is ousted.

The aforementioned procedures have for now been successfully invoked by the Prosecutor before the PTC I as the latter determined that he had competence to launch investigation of the type of crimes listed in Article 5 of the Statute and that it fulfilled the test pertaining to admissibility. By the same token, the PTC I stated that these procedures would entitle those against whom Arrest Warrants have been issued to mount a challenge against the jurisdiction of the Court over them. In short, no case can reach the Trial Chamber stage before all procedural hurdles have successfully been surmounted.

A perplexing issue is whether the principle of complementarity applies to a case that has been referred by the Security Council to the ICC. Although the Statute appears not to address this question the PTC I seems to accept that to be the case without questioning it. The present writer believes that there are two possible alternative interpretations: first, a referral by the Security Council carries with it the authority of Chapter VII, and this could obviate the need for invoking the principle of complementarity to the case at hand. The second interpretation is that, the principle under review applies to any and all cases, irrespective of the route which they chart to the ICC. This interpretation is consistent with Article 53 of the ICC Statute. The end of the second paragraph of that provision imposes a duty on the Prosecutor to inform the Security Council in case of a referral under Article 13 (b), of his decision whether to proceed or not. Apart from the two approaches to interpretation, it has to be appreciated that the question of admissibility refers to "cases", while referral by the Security Council relates to a "situation" suggesting that in the latter category a much broader concept is intended.

The applicability or otherwise of the principle of complementarity in a concrete case emanating from a Chapter VII referral is brought to the forefront in relation to the Darfur proceedings. This is a thorny issue and must be fully addressed by the PTC I before a proper hearing is convened before the ICC (See Note 37).

As concerns accountability and justice in Sudan, although it has been argued that the national court system is functional and has jurisdiction over human rights crimes perpetrated in Darfur, at a practical level these courts were said to have 
been unable to achieve much. It is argued in some quarters that the justice system as a whole appears to be unable or unwilling to prevent attacks. This was alleged to have been compounded by a general lack of independence and resources and ill-equiped police force and legislation that protect state officials from criminal litigation. Such allegations require thorough investigation.

As against that background, the Sudanese government took several initiatives to address impunity in Darfur. Thus, in the period between 2004 and 2006, it created five judicial and quasi-judicial organs with a mandate to ensure accountability for human rights crimes in Darfur. The available evidence suggests that these organs did not achieve the desired result. This may be illustrated by the limited success of the National Commission of Inquiry established in May 2004 to investigate crimes committed by armed groups. It appears that the Commission did not go beyond recommending "further investigations" into a number of specified incidents.

In addition to the foregoing, a number of ad hoc Investigatory Committees have been established in Darfur in response to incidents of attacks against civilians. Along with that, a number of Committees against rape were established to look into the issue of rape and sexual violence in Darfur. Several commentators have criticised these committees for being ineffective. Another body known as the Unit for Combating Violence against Women and Children was established but has failed so far to investigate specific cases.

The most elaborate attempt by the Government of the Sudan to create an accountability mechanism with conventional judicial elements was the establishment of the Special Criminal Court on the Events in Darfur (SCCED). Created by a decree of the Chief Justice, the SCCED was initially constituted as a panel of three judges, based in El Fasher, but with ability to circuit to any location deemed appropriate. It was granted wide jurisdiction covering all crimes in the Sudanese Penal Code and any charges concerning investigations into the violations cited in the report of the Commission of Inquiry and any charges pursuant to any other law, as determined by the Chief Justice. On 26 November 2005, the Chief Justice established two additional Special Criminal Courts for Nyala and El Geneina with the same jurisdiction as the initial SCCED, but with the addition of international humanitarian law (IHL). The SCCED statutes also contained explicit provisions on the right of observers from the AU or other entities to attend the court hearings (See Note 38).

The effectiveness of the SCCED has been limited at best. According to observers, of the nine known cases that came before it, verdicts were delivered in eight of them. A ninth case was initially heard but later dismissed. Only one of these cases dealt with the types of major violations of human rights and the laws of war that have characterized the conflict in Darfur. For example, in relation to an attack on Tama in South Darfur in October 2005. No one was found guilty of taking part or held responsible for orchestrating it (See Note 39). The men charged in connection with to the attack were found guilty only of stealing property at the site of the attack after it took place. Moreover, it seems to be the case that the SCCED has yet to address the issue of criminal responsibility of senior government officials, with the exception of trying one such official who was subsequently acquitted.

The government of Sudan has been consistent in its rejection of the legitimacy of the ICC as Darfur war criminals would be tried effectively under its national judicial system. A Sudanese Minister of State declared that the legal system of his country is one of the best in Africa and should be trusted to deliver justice to the suspected perpetrators of the Darfur war crimes. More significantly, he stated that: "The International Criminal Court efforts to try the Darfur war crime suspects should be complementary and should take place in cases where the government has shown clear unwillingness to provide justice." (See Note 40)

He added: "If there is fresh evidence, I can assure you everyone in government will be investigated and brought to justice". (See Note 41)

\section{Double Jeopardy}

The principle of double jeopardy is comparable in scope to the Latin maxim of ne bis in idem. It is enshrined in all the important human rights treaties such as the 1966 International Covenant on Civil and Political Rights (See Note 42). The core idea of this principle requires that nobody should be tried or punished twice for an offence for which he has already been convicted or acquitted. This principle is also enshrined in Article 20 of the Rome Statute (See Note 43). Paragraph 1 of that article stipulates that the ICC shall have no jurisdiction over a person that has either been convicted or acquitted by that Court. By contrast, paragraph 2 of the same article removes the competence of all other courts to deal with the crimes listed in Article 5 where the person involved has already been convicted or acquitted by the ICC. It should be emphasised that the restriction is only in relation to offences enumerated in Article 5 of the Statute. By necessary implication, therefore, prosecution by national courts for ordinary crimes resulting from the same behaviour is not barred. As can be readily seen, the prohibition is not absolute and perhaps this is in recognition of State sovereignty in relation to prosecution of ordinary crimes committed within its territory. In theory, the doctrine of double jeopardy seems to work without much difficulty, but in practice its application fails when criminal proceedings before domestic courts turn out to be sham in nature. In anticipation of such difficulties paragraph 3 of Article 20 made an 
exception which restores the jurisdiction of the ICC or other possible national courts where the previous proceedings in the domestic court had the purpose of shielding the accused from criminal liability for crimes within the jurisdiction of the ICC; or, where otherwise conducted without adhering to due process as recognized in international law. In practice, the application of the two limbs of the rule in paragraph 3 is not an easy matter. The judges will have to review the national proceedings in order to determine whether they were conducted for the purpose of shielding the offender from appearing before the ICC or were lacking in due process. Politically speaking, the judges will have to deal with a very sensitive issue, namely putting the legal system of the State in question on trial. It is almost certain that the State whose legal system is put under scrutiny will protest and may view the whole exercise as an unacceptable interference with its sovereignty. There is, however, a lacunae in the Rome Statute insofar as it does not address the situation in which an individual is properly prosecuted, but subsequently pardoned by the State. It would be recalled that Captain Kelly received a life sentence for the Mei Lei massacre in the Vietnam war, (See Note 44) but was pardoned within a brief spell. It would be of great interest to find out how the ICC would deal with a case the facts of which are comparable to that of Kelly's.

On $5^{\text {th }}$ December 2007 the Prosecutor of the ICC delivered a report to the Security Council detailing the failure of the Sudanese Government to arrest and surrender to the ICC the two men suspected of committing crimes against humanity and war crimes in Darfur. The Prosecutor indicated that the failure is so profound that the ICC has been effectively prevented from any further dealings with the case. Both men were free to move within Sudan, noting in particular that one of them was released from custody allegedly for lack of evidence and the other was subjected to a brief investigation and contemporaneous with that he received a ministerial appointment (See Note 45).

In conclusion, the Prosecutor indicated that their possible involvement in the atrocities committed in Darfur would never be investigated domestically.

\section{The Relationship Between the Security Council and the ICC}

One of the important questions raised as a result of the crisis in Darfur concerns the relationship between the Security Council and the ICC. The Security Council has been seized of the matter right from the time when the crisis erupted. It will be recalled that, the Security Council adopted Resolution 1564 on $18^{\text {th }}$ September 2004, creating an International Commission of Inquiry on Darfur to investigate violations of international humanitarian and human rights law. That Report was dully completed and submitted to the Security Council in January 2005. The findings of the Commission were so alarming in the sense that they accused the Government of Sudan and the Janjaweed of complicity in serious violations of international human rights and humanitarian law amounting to crimes under international law, and as these crimes were so widespread and systematic they might have constituted crimes against humanity. The Commission also accused rebel force from the JEM and SLA of complicity in serious violations of human rights and humanitarian law which might amount to war crimes.

Further Resolutions were also passed by the Security Council, dealing with the crisis in Sudan (See Note 46). Of special significance to the present enquiry is Resolution 1593 of 31 March 2005 which referred to the situation in Darfur to the ICC (See Note 47). The purpose of that Resolution was to allow the ICC to investigate and prosecute the alleged perpetrators of crimes in Darfur, including those identified by the International Commission of Enquiry.

We shall begin by analysing the Article in the Charter which deal with powers of the Security Council. Thus, Article 24(1) of the UN Charter confers upon the Security Council the primary responsibility for the maintenance of international peace and security'. And, paragraph (2) of the same Article makes express reference to the specific powers granted to the Security Council for the discharge of its duties in Chapters VI, VII, VIII and XII of the Charter. The framers of the Charter used the term 'primary responsibility' in Article 24 (1) as a way of characterizing the substantive and qualitative aspects of powers conferred upon the Security Council in the field of maintenance of peace as a whole (See Note 48). Examples of when such powers are exercised include, decisions binding upon Member States under Article 25, and ordering of sanctions against a delinquent State found guilty of an act of aggression or of a threat to the peace. As concerns the special powers listed in Chapters VI, VII, VIII and XII which are granted to the Security Council, they should not be viewed as conclusive (See Note 49). To suggest otherwise, would be inconsistent with the purposes of the UN Charter. Accordingly, Article 24(1) must therefore be seen as the basis of the comprehensive powers for the Security Council which exceeds those enumerated in the second paragraph of Article 24. This serves to fill in any potential gap within the powers of the Security Council (See Note 50). Pertinent to this, the question as to the meaning of the reference in Article 24(2) to the special powers of the Security Council under Chapters VI, VII, VIII and XII, has recently been considered within the framework of establishing the ICTY and the ICTR. Consideration was therefore given to the decisions based on Article 24, exclusively or jointly with Article 29 or directly on Article 29 alone. No conclusive decision had been reached in this respect, as the Security Council opted to act under Chapter VII as the issues fell within the ambit of Article 39 (See Note 51). The discussion may now conveniently proceed to Article 39 of the UN Charter. Under the terms of that provision, the Security Council is empowered to make a determination as to the existence of "any threat to the peace, breach of the peace or act of aggression". It may be noted at the outset that, the 
Security Council has unfettered discretion in this respect. In other words, the Council is under no obligation to come up with a determination in each end every instance.

Narrowing down the focus to internal armed conflicts, does the Security Council have the power to deal with them, or is it powerless as such conflicts do not in themselves constitute breaches of international peace? On the basis of contemporary practice of the Security Council, the preferred position is the former. This is the case now, notwithstanding that the original concept of threat to the peace contained in Article 39 related only to inter-state conflicts. Within a short space of time from the inception of the Charter, the Security Council practice confirmed that development. For an illustration, as early as 1948 the Security Council regarded the Palestinian conflict as a threat to the peace and security; and likewise the situation in the Congo in 1961 was also seen as one threatening the peace although external involvement was negligible.

As might be expected the Security Council had, in the post Cold War period continued with its liberal policy of characterizing internal conflicts as threat to the peace (See Note 52). Thus, without any reluctance the Security Council declared the heavy tribal fighting in Somalia caused a threat to the peace (See Note 53). Likewise, it came to the same conclusion with regard to the heavy fighting within the various Federal Republics in the former Yugoslavia (See Note 54). In subsequent practice, the Security Council was consistent in its attitude, but on occasions alluded to the need for the of fighting to be on a considerable scale, spilling over to neighboring countries, or affecting the stability of the region, as such. The internal conflicts concerned were in Angola, Liberia, Burundi, Rwanda, Sierra Leone, Central African Republic, East Timor and Albania (See Note 55). What may be gleaned from this review is that any internal strife of sufficient magnitude can be designated by the Security Council as a threat to international peace and security.

The same conclusions can also be said with respect to violations of human rights and humanitarian law. Thus, as early as 1965, when Rhodesia unilaterally declared its independence (UDI) from the UK, the Security Council condemned the racist regime and determined that the continuation of the UDI constituted a threat to the peace, not least because of its massive violation of human rights (See Note 56). A more recent example in 1991, when the Security Council characterised the repression of the population of Northern Iraq Kurdistan as a breach of the peace (See Note 57). It is noteworthy that the SC did not in its endorsement practice allude to cross border involvement. With regard to Somalia, the determination of threat to international peace and security was based on "the magnitude of the human tragedy",(See Note 58) while the underlying reason for the determination with regard to Rwanda and Eastern Zaire was said to be, "the magnitude of the humanitarian crisis"(See Note 59).

A final example that may be cited is Security Council Resolution 687 (1991). In the aftermath of the Gulf war, when the Security Council determined that the situation amounted to a "threat to the peace" and ordered certain measures, including the demarcation of boundaries between Iraq and Kuwait. Although, that Resolution was full of anomalies, not least because it omitted any reference to the principles of international law regulating disputed boundary, its legality was not contested.

The jurisprudential question is whether this line of practice amounts to customary international law. In order for that to happen the practice in question must be accepted as law. The International Court of Justice seems to apply one of two alternative options; the first involves a presumption in favour of the existence of an opinio juris on the basis of evidence of general practice. The second is more rigorous as it requires positive evidence of acceptance. As to which option the Court would follow, that would depend largely on the discretion of the Court bearing in mind the nature of the issue involved. Thus, in the Lotus Case, (See Note 60) the Permanent Court of International Justice (PCIJ) adopted the second criterion as evidenced by the following: "States had often, in practice, abstained from instituting criminal proceedings, and not that they recognized themselves as being obliged to do so; for only if such abstention were based on their being conscious of a duty to abstain would it be possible to speak of international custom." (See Note 61)

What emerges from the above is that, the PCIJ interpreted silence of States as lack of interest in the matter, rather than tacitly accepting the existence of the customary law rule in question. It is with justification that Professor Brownlie questioned the above statement, adding that the PCIJ had "misjudged the consequences of absence of protest and also the significance of fairly general abstention from prosecution by States other than the flag State"(See Note 62).

A question suggests itself here: are there any Charter provisions which fetter the discretion of the Security Council once Chapter VII is invoked? It seems to be the case that, the Security Council cannot act with total oblivion to two Charter provisions, namely, Articles 1(1) and 2(7). This is because the former imposes a general obligation on the Security Council to defer to 'principles of justice and of international law'; and the latter requires the Security Council not to intervene in matters which are essentially within the domestic jurisdiction of any Member States. It is submitted that, at the very least, the Security Council should always bare in mind these two provisions when determining what action to take, after a determination under Article 39. By the same token, the action taken must also be consistent with the principles of general international law. This requirement may be adhered to tacitly as happened in the case Resolution 731, when the Security Council simply attached the demands by the UK and USA in relation to the Lockerbie incident, without any reference to general international law. Failing that, the Resolution under which the Security Council 
purports to take action could be condemned as being ultra vires the Charter.

It must be appreciated that the Security Council would not be able to function, if decisions adopted by it under Chapter VII were not legally binding upon all Members of the United Nations. In order to avoid any potential difficulties, Article 25 requires the Members' agreement to accept and carry out the decisions of the Security Council in accordance with the United Nations Charter. It has to be noted, however, that Article 25 comes with its own complications as it is capable of differing interpretations. For example, one school of thought maintains that, the phrase 'in accordance with the present Charter' relates to the manner in which the Security Council reaches its decisions (See Note 63). It follows therefore, where a particular decision is not based on a Charter provision, it should have no binding effect. The second school of thought, on the other hand, maintains that the phrase in question relates to the obligation undertaken by the Members to obey the decisions of the Security Council (See Note 64). It is submitted that the former interpretation is to be performed. This position gains more grounds, particularly when Article 25 is read in conjunction with Article 103 which stipulates that in the event of a conflict between obligations arising under Chapter VII and those arising from other treaties, the former prevails. A closer examination of Article 103 reveals that it presupposes the intra vires nature of decisions taken under Chapter VII and has nothing to do with the criteria for establishing its legality. In short, Article 103 is merely concerned with the prevalence of obligations arising under Chapter VII over all other obligations entered into by the Member States, particularly those arising from treaty regimes.

In relation to the situation in Darfur, it needs to be emphasised here that, the UN Security Council has been continuously seized of it since it first erupted. For example, the Council adopted Resolution 1564, (See Note 65) giving mandate to the International Commission of Inquiry on Darfur to investigate violations of international humanitarian and human rights law. The specific mandate given to the Commission was: (1) to investigate reports of violations of international humanitarian law and human rights law in Darfur by all parties; (2) to determine whether acts of genocide have been committed or not; and (3) to identify the perpetrators of such violations with a view to making accountable those responsible. The Commission submitted its Report to the Security Council in January 2005. Its findings may be summarised as follows:

(1) The Sudanese Government and the Janjaweed were responsible for serious violations for international human rights and humanitarian law amounting to war crimes under international law.

(2) Condemnation of the Sudanese Government and the Janjaweed for being responsible for indiscriminating attacks, killing of civilian population, torture, enforced disappearances, destruction of villages, rape and other forms of sexual violence, pillaging and forced displacement, throughout the region of Darfur. The Commission concluded that these violations were carried out at such a large scale and systematic basis, that they could constitute crimes against humanity.

(3) As concerns rebel forces (JEM and SLA) the Commission also found credible evidence establishing responsibility for the commission of serious violations of human rights and humanitarian law, amounting to war crimes. The Commission, however, noted that the evidence relating to these groups did not disclose widespread and systematic violations.

Significantly, the International Commission recommended that the Security Council should formally refer the situation in Darfur to the ICC rather than to an ad hoc tribunal. Several reasons were provided for that preference: Firstly, as the ICC is situated at the Hague, it would be far away from the perpetrators sphere of influence and it would therefore ensure the administration of justice to the maximum; secondly, as the perpetrators are men of influence, perhaps their removal to The Hague could only be achieved by the joint efforts of the Security Council and the ICC; thirdly, it is anticipated that the ICC will be more efficacious than any other tribunal owing to the fact that its procedures are already set; fourthly, the cosmopolitan nature of the judges at the ICC, makes it a more appropriate body for conducting a fair and equitable trial; and fifthly, as compared with the other ad hoc criminal tribunals for the former Yugoslavia and Rwanda it is expected that the ICC will be more cost effective.

The efforts of the Security Council did not stop at Resolution 1593 (See Note 66) under which the situation in Darfur was referred to the ICC to deal with alleged perpetrators of crimes in Darfur, including those identified by the International Commission of Inquiry. The Security Council thereafter passed Resolution 1706 (See Note 67) explicitly reaffirming the elements of responsibility to protect as contained in the World Summit Outcome Document (2005). In that Resolution the Security Council determined again that the situation in Darfur constituted a threat to international peace and security. Moreover, it took a unanimous decision to deploy more than 20,000 peace-keeping forces to Darfur with a Chapter VII mandate, allowing for the use of force for civilians protection.

Resolution 1706 caused a storm of controversy among Sudanese leadership, as they accused the UN of helping Western endeavour to re-colonize Sudan. The Sudan Government asserted further that the presence of an international force in Darfur would attract terrorist in the region (See Note 68). Moreover, the Sudanese President Omar al-Bashir has invariably been insisting that the scale of the Darfur conflict has been exaggerated (See Note 69).

It is against this background that it is proposed to discuss some of the main issues relating to the relationship between 
the Security Council and the ICC. It stands reason that, as a matter of legal necessity, the latter must at the very least work in such a way that must not be wide off the mark from the primary responsibility of the Security Council for the maintenance of international peace and security.

With this in mind, three fields of operation need to be examined. The first is when the Security Council refers a situation to the ICC under Article 13(b) of the Rome Statute. This referral has in fact taken place for the first time ever in relation to the situation in Darfur. Thus, on 31 March 2005, the Security Council adopted unanimously Resolution 1593 (2005) after determining that the situation in Sudan continues to constitute a threat to international peace and security. It significant that in adopting its Resolution, the Security Council relied heavily on the report of the International Commission of Inquiry on Darfur. Pertinent to this, the determination made by the Security Council was exclusively based on that report, in spite of the fact there were other extensive reports readily available by other credible institutions such as Human Rights Watch (See Note 70).

The reason for this preference perhaps lies in the fact that the Report of the International Commission of Inquiry on Darfur was ordered by the Security Council under Chapter VII of the Charter (See Note 71). It was odd that although, Resolution 1593 referred the situation in Darfur, to the Prosecutor of the ICC to backdate his investigation to 21 July 2002, yet the Commission focused only on incidents which took place in the period from February 2003 to January 2005. This suggests that a period of seven months (July 2002 to February 2003) had not particularly been subjected to rigorous scrutiny by the Commission. Be that as it may, the Resolution demanded that all the disputing parties in Darfur, including the Sudanese Government, "shall co-operate fully with, and provide any necessary assistance to the Court and the Prosecutor pursuant to the Resolution". Thus, what is required from all concerned was full co-operation with the Prosecutor, and the provision of all necessary assistance to him. Seeing that the Resolution frankly acknowledges that non-members of the Rome Statute are under no obligation to co-operate, it is a bit odd to impose that obligation on Sudan as it is not a party to the Rome Statute.

The second area concerning the relationship between the ICC and the UN Security Council is covered by Article 16 of the Statute. Under that provision, the Security Council could ask the Prosecutor of the ICC to defer any particular investigation for a period of twelve months, through a Resolution adopted under Chapter VII of the UN Charter. An important aspect of this form of deferral is that it is renewable. This means that, if the Security Council is taking action under Chapter VII, the Prosecutor of the ICC must defer investigating crimes, even though they happen to be within the jurisdiction of the ICC, for as long as measures under Chapter VII are being pursued.

In this respect, the Security Council stated in the preamble of Resolution 1593 as follows: "Recalling article 16 of the Rome Statute under which no investigation or prosecution may be commenced or proceeded with by the International Criminal Court for a period of 12 months after a Security Council request to that effect..."

What is suggested here is two fold: Firstly, the Security Council could at any stage exercise its powers by asking the ICC for a deferral of the Darfur case for at least one calendar year. Secondly, albeit implicitly the Security Council was not contemplating to invoke its aforesaid powers of deferral.

The third area in which the relationship between the Security Council and the ICC needs to be looked at, concerns the crime of aggression. Although, Article 5 of the Statute of Rome stipulates that the ICC has jurisdiction over the crime of aggression, it cannot exercise that jurisdiction until the offence in question is defined. And, apparently this definition must be consistent with the relevant provisions of the UN Charter. The need for the Security Council and the ICC to work harmoniously together arises from the fact that it is the Security Council which determines, under Article 39 of the Charter, whether an act of aggression has taken place. Thus, in future if the Prosecutor of the ICC is investigating whether a given act amounts to aggression, he must ensure that what he is doing is not inconsistent with what the Security Council is doing in that respect. In short, the relationship between the Security Council's exercise of its powers under Chapter VII and the ICC exercise of jurisdiction over the crime of aggression is most crucial. The key point now is that, the debate is still ongoing in an attempt to find a definition of aggression and the possibility of an appropriate amendment of the Rome Statute. The crime of aggression in the context of the Darfur investigation is of academic interest only, not least because the ICC has as yet to acquire jurisdiction over it.

\section{Conclusion}

Some see the adoption of Resolution 1593 by the Security Council as a stand against impunity and an expression of confidence in the ICC to handle complex cases. On the face of it, the Security Council can be seen as sending a message that there is no one who can get away without retribution for grave crimes. Moreover, the referral of the situation in Darfur to the ICC can be viewed as a means for enhancing the Council's conflict prevention and resolution capabilities. This is all very well, but Sudan, the target State, is not a party to the Rome Statute, and without its cooperation the implementation of the Resolution becomes fraught with procedural impediments and practical difficulties. This is independently of whether the Sudan is under legal obligation or otherwise to comply with the referral Resolution taken under Chapter VII of the Charter. As against that, the Sudanese government and its supporters see the adoption of the 
Resolution as an exploitation of the Crisis in Darfur as part of domination of weak countries by the big powers.

The jurisdiction of the ICC centres around the contentious issues of unwillingness and inability of the State to deal with, to investigate and prosecute an individual for crimes listed in the Statute. Unwillingness in a particular case may be established when the ICC concludes that the national proceedings were or are being conducted for the purpose of shielding the perpetrator, or whether the proceedings were a sham. Inability may be illustrated by the total or partial collapse of the State, or its legal system.

As concerns the crimes in Darfur, there is a general belief among human rights organisations that attempts of the Sudanese government to present those guilty of committing atrocities in Darfur are bogus. The Sudanese government is strongly opposed to that.

What may be gleaned form the debate on the concepts of 'unwillingness and unable' is that, complementarity is not so simple when it comes to implementation. One has to consider difficulties which may arise when considering the subjective versus the objective criterion to be applied by the ICC when no proceedings are commenced by the national court. Moreover, it is not even certain whether complementarity with all its attending exceptions and circumstances apply to cases of referral from the Security Council.

The case of Darfur raises serious issues of a possible conflict between the principle of sovereignty of the State and the policy behind the administration of criminal justice at an international level.

The issue of establishing the jurisdiction of the ICC (or admissibility of a case before the ICC as known in the Rome Statute) in relation to Darfur is not safe from contradictions. First of all, the Prosecutor has gathered his evidence from witnesses and organisations based in 17 countries outside Sudan. The justification for that is understandable but it is question begging whether a conviction based on that sort of evidence can be safe. Moreover, the issue of identifying only two individuals for prosecution at the ICC (now three) makes the selection procedure questionable, and also raises issues with regard to the randomness of the choice and the objective to be achieved.

Leaving that aside, the Prosecutor of the ICC should continue to retain complete objectivity about bringing the two Sudanese suspects for trial at The Hague. In so doing, he is expected to be conscious about the existence of parallel non-judicial means of settling the dispute and ending the fighting. After all, the Rome Statute empowers him to discontinue a case at any stage in the proceedings. He is empowered to do that, because a trial at The Hague might not be in the interest of the peace of the country concerned at large.

Furthermore, perhaps the time may have come for him to consider prosecuting the accused inside Sudan by a specially constituted criminal court which should be subject to international supervision. The presence of the international element will ensure impartiality as evidenced by the Lockerbie trial.

Finally, it must be conceded that the international community has different views and no common position with regard to the matter.

In this respect, neither the Arab League nor the African Union seem to offer any support for the prospect of holding the trial at the ICC. As to the Security Council, the support for such trials comes from the United States, the United Kingdom and France. The question is bagged whether justice will be seen to be done in such circumstances.

\section{References}

Brown D. (1999). The International Criminal Court and Trial in Absentia. Brooklyn Journal of Int'l Law, 24, pp 763-96. Brownlie I. (2003). Principles of Public International Law (6 ${ }^{\text {th }}$ ed.). Oxford, Oxford University Press.

Evans, M.D. (2003). Blackstone's International Law Documents ( $6^{\text {th }}$ ed.). Oxford, Oxford University Press.

Schabas W. (2004). An Introduction to the International Criminal Court ( $2^{\text {nd }}$ ed.). Cambridge, Cambridge University Press.

Simma B. (2002). The Charter of the United Nations a Commentary (2 ${ }^{\text {nd }}$ ed.) Vol. 1.

Von Hebel H. \& Robinson D. (1999). Crimes Within the Jurisdiction of the Court. In R.S. Lee, The International Criminal Court: The making of the Rome Statute - Issues, negotiations, results (pp 79-85) The Hague, Kluwer.

Weller M. (1992). The International Response to the Dissolution of the Socialist Federative Republic of Yugoslavia A. J. I. L. 86, pp 569-607.

Williams S. (1999). Issues of Admissibility. In O. Triffterer Commentary on the Rome Statute of the International Criminal Court (pp 383-392) Baden-Baden, Nomos.

\section{United Nations Documents}

Human Rights Council, Report of the High-Level Mission on the situation of human rights in Darfur, Sudan pursuant to Human Rights Council decision S-4/101 (7 March 2007) A/HRC/4/80 
(http://daccessdds.un.org/doc/UNDOC/GEN/G07/116/20/PDF/G0711620.pdf? Open Element).

Second Periodic Report of the United Nations High Commissioner for Human Rights on the Human Rights Situation in Sudan (27 January 2006) (http://www.ohchr.org/Documents/Countries/sudanjanuary06.pdf).

Fourth Report of the ICC Prosecutor to the UN Security Council pursuant to UNSC Resolution 1593 (2005) (http://www.icc-cpi.int/library/organs/otp/OTP_ReportUNSC4-Darfur_English.pdf).

Security Council Resolution Referring Situation in Darfur, Sudan to the ICC, (31.03.2005) Press Release SC/8351 (http://www.un.org/News/Press/docs/2005/sc8351.doc.htm).

Report of the International Commission of Inquiry on Darfur to the UN Security Council, 25.1.2005 ( http://www.icc-cpi.int/library/cases/Report_to_UN_on_Darfur.pdf).

Statute of the ICT Rwanda (1994) UN DOC S/RES/955, Annex (http://www.unhchr.ch/Huridocda/Huridoca.nsf/0/ec13479ff41ef7fd8025681e004113b5? Open Document).

Statute of the ICT for the former Yugoslavia (1993) UN DOC. S/RES/ 827, Annex.

Charter of the International Military Tribunal (IMT) in Agreement for the Prosecution and Punishment of the Major War Criminals of the European Axis, Annex (1951) 82 U.N.T.S 279.

Repertoire of the Practice of the Security Council (1952-5) UN. Doc. ST/PSCA/Add.1.

UN Security Council Resolution 217 (20.11.1965) UN DOC. S/RES/217.

UN Security Council Resolution 733 (23.1.1992) UN DOC. S/RES/733.

UN Security Council Resolution 794 (3.12.1992) UN DOC. S/RES/794.

UN Security Council Resolution 788 (9.11.1993) UN DOC. S/RES/788.

UN Security Council Resolution 918 (17.05.1994) UN DOC. S/RES/918.

UN Security Council Resolution 929 (22.06.1994) UN DOC. S/RES/929.

UN Security Council Resolution 1072 (30.08.1996) UN DOC. S/RES/1072.

UN Security Council Resolution 1078 (9.11.1996) UN DOC. S/RES/1078.

UN Security Council Resolution 1101 (28.03. 1997) UN DOC. S/RES/1101.

UN Security Council Resolution 1564 (18.09.2004) UN DOC. S/RES/1564.

UN Security Council Resolution 1593 (13.03.2005) UN DOC. S/RES/ 1593.

UN Security Council Resolution 1706 (31.08.2006) UN DOC. S/RES/1706.

UN Security Council Resolution 688 (5.04. 1991) UN DOC. S/RES/688.

UN Security Council Resolution 1125 (6. 08. 1997) UN DOC. S/RES/1125.

UN Security Council Resolution 1132 (8. 10. 1997) UN DOC. S/RES/1132.

UN Security Council Resolution 1264 (15. 09.1999) UN DOC. S/RES/1264.

UN Security Council Resolution 864 (15.9. 1993) UN DOC. S/RES/ 864.

\section{Cases}

Lotus case (France v. Turkey), PCIJ, judgement of 7 September 1927, Series A, no 10.

Prosecutor v. Akayesu, ICTR, Trial Chamber I, judgement of 2 September 1998, Case no. ICTR/96/4/T.

Prosecutor v. Blaskic, ICTY Trial Chamber I, judgment of March 2000, Case no. IT/95/14/T.

Prosecutor v. Clement Kayishema and Obed Ruzindana, ICTR, Trial Chamber II, Judgement of 21 May 1999, Case no. ICTR/95/1/T.

Prosecutor v. Jelisic, ICTY, Trial Chamber I, judgement of 14 December 1999, Case no. IT/95/10/T.

Prosecutor v. Tadic, ICTY Trial Chamber II, judgment of May1997, Case No.IT/94/1/T.

\section{ICC cases and documents}

ICC, PTC I (27 April 2007) The Prosecutor v. Ahmad Muhammad Harun ("Ahmad Harun") and Ali Muhammad Ali Abd-Al-Rahman ("Ali Kushayb") Case No. ICC-02/05 - 01-07.

ICC, Fact Sheet on the Situation in Darfur, the Sudan, 27.02. 2007 (http://www.icc-cpi.int/library/organs/otp/ICC-OTP_Fact-Sheet-Darfur-20070227_en.pdf).

ICC, Decision of PTC I (27 February 2007) Case No. ICC-02/05- 01/07. 


\section{Other sources}

Minteer K. (December 2007) ICC Prosecutor Reports on Sudan's Obstructionism (http://www.humanrightsfirst.org/media/ij/2007/statement/393/).

Human Rights Watch (November 2007) Memorandum for the Sixth Session of the International Criminal Court Assembly of State Parties.

Glassborow K. Analysis, Sudan to hold own Darfur trials, Middle East Times, 9/9/2007.

http://english.aljazeera.net/NR/exeres/16A19A39-6983-4D0C-8FB2-22765C198717.htm (May 2007).

http://news.xinhuanet.com/english/2007-03/25/content_5892057.htm (March 2007).

Human Rights Watch (December 2005) Sudan, Entrenching Impunity- Government Responsibility for International Crimes in Darfur, Vol. 17 No 17 (a).

http://www.alertnet.org/printable.htm?URL=/thenews/desk/N19319954.htm.

http://www.sudantribune.com/spip.php?=page=imprimable\&id_article=20960.

http://www.vuanews.com/english2007-03-05.

Digest of U.S Practice in International Law (1975) Office of the Legal Adviser, Department of State, 1974-1986, Annual, Washington, DC.

\section{Notes}

Note 1. http://www.alertnet.org/printable.htm?URL=/thenews/desk/N19319954.htm.

Note 2. For up-to-date information see Department for International Development, country profiles: Africa (Sudan), $3^{\text {rd }}$ December 2007.

Note 3. See generally Second Periodic Report of the United Nations High Commissioner for human rights on the Human Rights Situation in Sudan (27 January 2006) pp 11- 18.

Note 4. Minteer K. (December 2007) ICC Prosecutor Reports on Sudan's Obstructionism (http://www.humanrightsfirst.org/media/ij/2007/statement/393/).

Note 5. Charter of the International Military Tribunal (IMT) in Agreement for the Prosecution and Punishment of the Major War Criminals of the European Axis, Annex (1951) 82 U.N.T.S 279,Art 6.

Note 6. Statute of the ICT for the former Yugoslavia (1993) UN DOC. S/RES/ 827, Annex.

Note 7. Statute of ICT Rwanda (1994) UN DOC S/RES/955, Annex.

Note 8. See also Ibid Article 1.

Note 9. Text: Evans, M.D. (2003) Blackstone's International Law Documents. (6 ${ }^{\text {th }}$ ed.) Oxford, Oxford University Press pp 36-38.

Note 10. Prosecutor v. Akayesu, ICTR, Trial Chamber I, judgement of 2 September 1998, Case no. ICTR/96/4/T.

Note 11. Ibid.

Note 12. Prosecutor v. Clement Kayishema and Obed Ruzindana, ICTR, Trial Chamber II, Judgement of 21 May 1999, Case no. ICTR/95/1/T.

Note 13. Ibid.

Note 14. Prosecutor v. Jelisic, ICTY, Trial Chamber I, judgement of 14 December 1999, Case no. IT/95/10/T.

Note 15. Ibid.

Note 16. Ibid.

Note 17. Report of the International Commission of Inquiry on Darfur to the UN Security Council (25.1.2005) at page 4.

Note 18. Ibid.

Note 19. Fourth Report of the ICC Prosecutor to the Security Council pursuant to UNSC Resolution 1593 (2005).

Note 20. Prosecutor v. Tadic, ICTY Trial Chamber II, judgment of May1997, Case No.IT/94/1/T at par. 646.

Note 21. Prosecutor v. Blaskic, ICTY Trial Chamber I, judgment of March 2000, Case no.IT/95/14/T par. 257.

Note 22. Fourth Report of the ICC Prosecutor to the Security Council pursuant to Resolution 1593 (2005).

Note 23.ICC, Fact Sheet on the Situation in Darfur, the Sudan, 27.02. 2007 (http://www.icc-cpi.int/library/organs/otp/ICC-OTP_Fact-Sheet-Darfur-20070227_en.pdf). 
Note 24. ICC, Decision of PTC I, 27 February 2007 Case No.ICC-02/05- 01/07.

Note 25. Ibid.

Note 26. http://www.sudantribune.com/spip.php? =page=imprimable\&id_article=20960.

Note 27. Von Hebel H. \& Robinson D. (1999). Crimes Within the Jurisdiction of the Court. In R.S. Lee, The International Criminal Court: The making of the Rome Statute - Issues, negotiations, results (pp 79-85) The Hague, Kluwer, pg 124.

Note 28. See supra note 24.

Note 29. Schabas W. (2004) An Introduction to the International Criminal Court (2 ${ }^{\text {nd }}$ ed.) Cambridge, Cambridge University Press, at pg 69.

Note 30. UN Security Council Resolution 1593 (13.03.2005) UN DOC. S/RES/ 1593.

Note 31. http://english.aljazeera.net/NR/exeres/16A19A39-6983-4D0C-8FB2-22765C198717.htm.

Note 32. Human Rights Watch (December 2005) Sudan, Entrenching Impunity- Government Responsibility for International Crimes in Darfur, Vol. 17 No 17(a) at pg 70.

Note 33. ICC, Situation in Darfur, Sudan, The Prosecutor v. Ahmad Muhammad Harun ("Ahmad Harun") and $\square$ Ali Muhammad Ali Abd-Al-Rahman ("Ali Kushayb") Case No. ICC-02/05 - 01-07, 27 April 2007.

Note 34. See supra note 26.

Note 35. Brown D. (1999) The International Criminal Court and Trial in Absentia. Brooklyn Journal of Int'1 Law 24, (pp 763-96) at pg 763.

Note 36. See Williams S. (1999) Issues of Admissibility. In O. Triffterer Commentary on the Rome Statute of the International Criminal Court (pp 383- 392) Baden-Baden, Nomos at pg 393.

Note 37. K. Glassborow, Analysis, Sudan to hold own Darfur trials, Middle East Times, 9/9/2007.

Note 38. Human Rights Council, Report of the High-Level Mission on the situation of human rights in Darfur pursuant to Human Rights Council decision S-4/101, A/HRC/4/80 (7 March 2007) at pg 17, para 50.

Note 39. Ibid.

Note 40. http://news.xinhuanet.com/english/2007-03/25/content_5892057.htm.

Note 41. Ibid.

Note 42. Article 14(7) text: Evans, M.D. (2003) Blackstone's International Law Documents. (6 ${ }^{\text {th }}$ ed.) Oxford, Oxford University Press at pg 99.

Note 43. Text: Schabas W. (2004) An Introduction to the International Criminal Court ( $2^{\text {nd }}$ ed.) Cambridge, Cambridge University Press at pg 210.

Note 44. Digest of U.S Practice in International Law (1975) Office of the Legal Adviser, Department of State, 1974-1986, Annual, Washington, DC.

Note 45. Human Rights Watch (November 2007) Memorandum for the Sixth Session of the International Criminal Court Assembly of State Parties at pg 2.

Note 46. Resolution 1590 of 24 March 2005, establishing the United Nations Mission in Sudan (UNMIS) and authorised deployment of up to 10,000 military personnel, plus a civilian component for a UN Peace Support operation to support the Comprehensive Peace Agreement; Resolution 1591 of 29 March 2005, imposing an arms embargo on all the parties in Darfur and provided for travel bans and the freezing of assets of individuals who continue to violate commitments to end the conflict.

Note 47. Security Council Resolution Referring Situation in Darfur, Sudan to the ICC, (31.03.2005) Press Release SC/8351 (http://www.un.org/News/Press/docs/2005/sc8351.doc.htm).

Note 48. Simma B. (2002) The Charter of the United Nations a Commentary (2 ${ }^{\text {nd }}$ ed.) Vol. 1 at pg 446, para 8.

Note 49. Ibid para 5.

Note 50. Ibid.

Note 51. Ibid, p 451, para 20.

Note 52. Repertoire of the Practice of the Security Council (1952-5) UN. Doc. ST/PSCA/Add.1 at page 159.

Note 53. UN Security Council Resolution 733 (23.1.1992) UN DOC. S/RES/733.

Note 54. See, Weller M. (1992) The International Response to the Dissolution of the Socialist Federative Republic of 
Yugoslavia A. J. I. L. 86, pp 569-607 at pp 577-81.

Note 55. For Angola see UN Security Council Resolution 864 (15.9. 1993) UN DOC. S/RES/ 864; For Liberia, see UN Security Council Resolution 788 (9.11.1993) UN DOC. S/RES/788; For Burundi see UN Security Council Resolution 1072 (30.08.1996) UN DOC. S/RES/1072; For Rwanda UN Security Council Resolution 918 (17.05.1994) UN DOC. S/RES/918; For Sierra Leone, UN Security Council Resolution 1132 (8. 10. 1997) UN DOC. S/RES/1132; For Central African Republic, UN Security Council Resolution 1125 (6. 08. 1997) UN DOC. S/RES/1125 ; For East Timor, UN Security Council Resolution 1264 (15. 09.1999) UN DOC. S/RES/1264 ; For Albania UN Security Council Resolution 1101 (28.03. 1997) UN DOC. S/RES/1101.

Note 56. UN Security Council Resolution 217 (20.11.1965) UN DOC. S/RES/217.

Note 57. UN Security Council Resolution 688 (5.04. 1991) UN DOC. S/RES/688.

Note 58. UN Security Council Resolution 794 (3.12.1992) UN DOC. S/RES/794.

Note 59. For Rwanda see UN Security Council Resolution 929 (22.06.1994) UN DOC. S/RES/929; for Zaire see UN Security Council Resolution 1078 (9.11.1996) UN DOC. S/RES/1078.

Note 60. Lotus case (France v Turkey), PCIJ, judgement if 7 September 1927, Series A, no 10.

Note 61. Ibid page 18 .

Note 62. I. Brownlie, Brownlie I. (2003) Principles of Public International Law (6 ${ }^{\text {th }}$ ed.) Oxford, Oxford University Press, at pg 8.

Note 63. Simma. B. supra note 49 at pg 455, para 6.

Note 64. Ibid.

Note 65. UN Security Council Resolution 1564 (18.09.2004) UN DOC. S/RES/1564.

Note 66. UN Security Council Resolution 1593 (13.03.2005) UN DOC. S/RES/ 1593.

Note 67. UN Security Council Resolution 1706 (31.08.2006) UN DOC. S/RES/1706.

Note 68. http://www.vuanews.com/english2007-03-05.

Note 69. http://www.vonews.com/english/2007-03-05.

Note 70. Human Rights Watch supra note 32.

Note 71. UN Security Council Resolution 1564 (18.09.2004) UN DOC. S/RES/1564. 